DOI: https://doi.org/10.32839/2304-5809/2021-6-94-32

УДК 37.378

Деркач Ю.Я., Лавро О.О.

Львівський національний університет імені Івана Франка

\title{
ПРОФЕСІЙНА ПІДГОТОВКА ВЧИТЕЛІВ ПОЧАТКОВИХ КЛАСІВ ВЕЛИКОБРИТАНІЇ
}

Анотація. Ця стаття висвітлюе проблему підготовки вчителів у Великобританіі. Були зроблені спроби розглянути спеціальні викладацькі кафедри багатьох університетів Великобританії, а також, питання навичок групового навчання та самостійної роботи студентів. Сформульовано головну ідею нового методу навчання за кордоном, а саме: студенти не $є$ пасивними слухачами, а активними учасниками навчального процесу. Велика увага приділяеться обов’язковому вихованню вчителів-дослідників як важливої потреби сучасного суспільства. Досліджено, що наукові навички майбутніх учителів культивуються у процесі навчання системи вищої професійної освіти. Визначено, що у европейській освіті, зокрема у Великобританії, тривае процес розробки та впровадження нової моделі професійної підготовки вчителів початкових класів, яка відповідає вимогам единого европейського простору вищої освіти та має спільні характеристики 3 іншими країнами ЄC, а саме: педагогічна освіта базуеться на трьох домінантних моделях (технологічній, гуманістичній, функціональній орієнтації), а пріоритет у підготовці вчителя надається концепціям: загальній персоналістичній, прагматичній, методичній, неопозитивістській, гуманістичній.

Ключові слова: професійна підготовка, освітній процес, вчитель початкових класів, система вищої освіти, Великобританія.

Derkach Yuliya, Lavro Olha Ivan Franko National University of Lviv

\section{PROFESSIONAL TRAINING OF PRIMARY SCHOOL TEACHERS IN GREAT BRITAIN}

Summary. The R\&D is devoted to the problem of the professional training of future primary school teachers in higher education institutions in the UK and Ukraine. The social and historical preconditions of formation of modern systems of professional training of teachers in Great Britain and Ukraine are analyzed, the structure of the system of higher education and its organizational characteristics are analyzed. In accordance with the stages of formation and development of teacher training, the historical stage of functioning of primary pedagogical education in Great Britain has been determined. A comparative analysis of models of training future primary school teachers in the British and Ukrainian education systems. The paper analyzes the content of teaching, technology, forms and methods of teaching future primary school teachers in the UK and Ukraine. The essence of the concept of "system" is explained. An attempt is made to explore the main mechanisms and tools for implementing new strategies at the level of higher professional education. The common and distinctive features of the components of the content of teacher training of both countries are revealed. The essence, content and organizational principles of pedagogical practice are revealed. The role of practice in the formation of professional skills of future teachers in Ukraine and the United Kingdom is demonstrated. The issue of experience in organizing methodological support for future primary school teachers is generalized. Based on the results of comparative analysis, a theoretical approach to the formation of content, choice of organizational form and methods of professional training of future primary school teachers, covering the main types of educational programs for primary school teachers in the UK. In order to improve the Ukrainian system of primary school teacher training, methodological recommendations have been formulated on the possibility of creative use of the experience of professional training of British teachers.

Keywords: vocational training, elementary school teacher, educational content, pedagogical practice, comparative analysis.

Постановка проблеми. Важливим полем для наукового аналізу за останні десятиліття $є$ грунтовний порівняльно-педагогічний аналіз освітніх систем, зокрема конкретні напрями редрормування вищої школи країн Свропи, а також інтеграційні процеси в европейській освіті. Цей фрактор зумовлений ще далеким підписанням Болонської декларації і проголошення Лісабонської стратегії наприкінці XX століття. Проблема полягає у відсутності систематизованої інформації про досвід та тенденцій розвитку профресійної підготовки майбутніх учителів початкової школи у Великобританії.

У процесі побудови сучасного демократичного суспільства стрімко змінюеться роль учителів, їхні фрункції, підготовка і діяльність. У міжнародних нормативно-правових актах глобального характеру (Педагогічна Конституція Свропи, Рекомендації ЮНЕСКО, документи Міжнародної
Організації Праці, тощо) учителі XXI століття проголошуються носіями суспільних змін. Формування освітянської еліти, рівень її кваліфрікації, загальної культури, духовності суттево впливає на майбутне будь-якої країни. Саме вчитель $є$ головним складником у формуванні людського потенціалу держави, її конкурентоспроможності, адже базові моральні й громадянські цінності, знання майбутніх учених, медиків, інженерів, менеджерів, музикантів, конструкторів закладаються у школі.

Аналіз останніх досліджень і публікацій. Серед дослідників-компаративістів України питання системи освіти Великої Британії у різних напрямах досліджували: теорію і практику британської загальноосвітньої школи (М. Алексевич, М. Лещенко, О. Локшина, О. Матвієнко, А. Сбруєва), вищу і профресійну освіту (Н. Бідюк, О. Глузман, О. Кузнецова), освіту дорослих (С. Ко- 
валенко). 3 поміж них чільне місце належить науковим дослідженням у галузі педагогічної освіти, які виконувалися переважно на матеріалах Англії й Уельсу і стосувалися особливостей професійної підготовки вчителів в умовах інтеграціі (Л. Пуховська), стандартизації педагогічної освіти (Н. Авшенюк), формування педагогічної майстерності вчителів (Ю. Кіщенко), редормування вищої педагогічної освіти (А. Парінов), розвитку післядипломної педагогічної освіти (С. Синенко)

Виділення не вирішених раніше частин загальної проблеми. Аналіз сучасних досліджень із порівняльної педагогіки засвідчив, що на початку XXI ст. система педагогічної освіти Великої Британії продовжуе активно редрормуватися; проблема підготовки вчительських кадрів у межах системи продесійно-педагогічної освіти залишаються недостатньо вивченими, зокрема не повною мірою розкривається теоретичний і практичний досвід процесу підготовки вчителів і шляхи творчого використання цього досвіду в Україні. Потребує перегляду наявна практика запозичення зарубіжного досвіду без об'єктивного аналізу і критичного підходу.

Мета статті. У статті ми розглядаємо питання аналізу, узагальнення та порівняння теоретичних ідей та практичного досвіду професійного навчання вчителів початкових класів у Великобританії та Україні. Вважаємо за необхідне окреслити елементи, які можуть бути використані в Україні, як позитивний сучасний досвід підготовки британських вчителів початкових класів. На основі проаналізованої інформації, описати характеристики моделей професійної підготовки вчителів початкових класів у навчальних закладах Великобританії та України. Відповідно до Нащіонального стандарту для кваліфікованих викладачів (Великобританія) та Стандарту вищої освіти за спеціальністю 013 Початкова освіта (Україна) провести порівняльний аналіз нащіональних державних вимог до профресійної підготовки вчителів початкових класів України та Великобританії.

Виклад основного матеріалу. Великобританія є однією з найбільш розвинених країн, саме тому, нас приваблюе досвід ціё̈ країни, зокрема ті елементи системи вищої освіти, які сприяють якісному та прогресивному розвитку профресійної підготовки вчителів. Звісно ж, спостерігаються загальні тенденції розвитку зарубіжної системи освіти в умовах глобалізації. Великобританія має різноманітні традиції в організації системи педагогічної освіти, постійно вдосконалюе та виводить на новий рівень підготовку майбутніх учителів, забез печуючи методологічні й методичні засади глибоким психолого-педагогічним супроводом, орієнтованим на практику. Основним державним документом, який є стрижнем провідних процесів стандартизації педагогічної освіти Великої Британії, є Національний стандарт кваліфікованого вчителя. Стандарти, необхідні для здобуття статусу кваліфікованого вчителя, містять такі категорії:

1) додаткові стандарти для навчання й виховання наймолодших учнів;

2) знання та розуміння;

3) контроль, атестування, облік і звітування;
4) планування, навчання та керівництво класом (стандарти для початкового навчання англійської мови, математики та природничих дисциплін, планування).

Дослідження показало, що стандарти викладені чітко і послідовно з окремим визначенням мети та завдань для кожного етапу навчання. Профресіоналізм учителя ставиться вище від рівня механічного виконання низки спеціалізованих стандартів. Високо оцінюються творчий внесок, енергія й ентузіазм, розумові та керівні здібності, яких вимагає профресія вчителя, як невід'ємні складники компетентності висококваліфрікованого фрахівця. Під час атестування перевіряеться відповідність майбутніх учителів цим стандартам у їх сукупності та взаємозв'язку.

Здобувачі кваліфікації вчителя з усіх предметів і на всіх рівнях під час атестування повинні продемонструвати такі знання та вміння:

- знання обсягу і змісту навчального матеріалу, визначеного Державною програмою для учнів із базових початкових та основних предметів і релігійних дисциплін;

- знання з їхніх спеціальних предметів і здатність бездоганно навчати цих предметів на рівні середньої школи;

- для фрахівців з англійської мови, математики або природничих дисциплін знання й розуміння змісту предметів, що регламентується Державною програмою початкової підготовки вчителя;

- розуміння взаємозв'язку між успіхом у навчанні і фрізичним, розумовим, емоційним і соціальним розвитком учнів;

- знання програм шкільного релігійного навчання викладачами релігійних дисциплін;

- розуміння завдань, обсягу та структури вимог Державної програми загалом, місця початкового етапу, мети і цілей початкових базових предметів і релігійних дисциплін.

Нащіональний стандарт кваліфрікованого вчителя Великої Британії включає три розділи [13, с. 4]: профресійні ознаки (Professional attributes); професійні знання i розуміння (Professional knowledge and understanding); профресійні навички (Professional skills). Перший розділ Національного стандарту кваліфрікованого вчителя містить дев'ять напрямів:

1. Покладаючи великі надії на кожного учня, вчитель виявляе упевненість, що вони зможуть досягнути високих результатів у навчанні.

2. Учитель власним прикладом демонструє такі позитивні цінності, ставлення і поведінку, які він очікуе від своїх учнів.

3. Здійснюе ефрективне та толерантне спілкування $з$ дітьми, колегами, батьками та опікунами.

4. Підвищуе свій профресійний рівень, постійно працюючи над собою, використовуе критичний самоаналіз та прислуховується до оцінки колег; він мотивований на подальший продесійний розвиток.

5. Розуміе і поважає внесок колег, батьків та учнів у забезпечення добробуту дітей та покращення навчально-виховного процесу.

6. Уміе працювати в команді вчителів, тобто має так званий «колективний профресіоналізм».

7. Постійно знаходиться у творчому пошуку, намагаючись вдосконалити свій профресійний рівень. 
8. Має творчий і критичний підхід до інновацій, використовуе нові форми і методи для покращення навчального процесу.

9. Учитель повинен завжди мати зворотній зв'язок з учнями і бути відкритим для допомоги і підтримки [13, с. 12].

В цьому документі велика увага приділяеться умінню вчителя створювати сприятливу атмосферу в навчально-виховному процесі (співпраця з колегами та батьками, постійний взаемозв'язок 3 учнями). На нашу думку, при такому підході можливе забезпечення ефективного і творчого процесу на шляху індивідуального розвитку та професійної інтегрованості.

У другому розділі викладені загальні вимоги до рівня знань учителя. У документах вказуеться, що для отримання статусу кваліфрікованого вчителя майбутні спеціалісти початкової школи повинні володіти Ірунтовними знаннями з фундаментальних дисциплін, які створюють ядро Національного курикулуму шкільної освіти (англійська мова, математика, природознавство), вміти впроваджувати в навчальний процес Національні стратегії мовної та числової грамотності. Також учитель початкової школи має бути готовим до викладання наступних предметів: інформаційні та комунікаційні технології; історія або географрія; фрізична культура; мистецтво і дизайн; сценічні мистецтва; релігійна освіта. Вчитель має вміти оцінювати навчальні успіхи учнів згідно з вимогами й показниками, визначеними цілями навчання дітей раннього віку, зафіксованими у Національному курикулумі шкільної освіти, викладеними у Національних професійних кваліфікаціях, а також керуючись національними щілями і стратегіями; знати і розуміти цілі, завдання і загальні вимоги Національного навчального плану шкільної освіти. Окрім цього вчителю треба розуміти принципи поетапності в навчанні й враховувати їх у своїй педагогічній праці, знати про зміни та інновації в педагогічній теорії та практиці, ефективно використовувати інформаційно-комунікаційні технології у навчальному процесі та професійному розвитку, розуміти вплив фізичного, інтелектуального, етнічного, соціального, культурного та емоційного розвитку учнів на їх навчальні результати, розуміти свою відповідальність за навчання дітей, які не $є$ носіями англійської мови, або дітей зі спеціальними потребами, та консультуватися з відповідними спеціалістами [13, с. 17].

Третій розділ Національного стандарту містить декілька напрямів:

1. Використання різних методів контролю знань і умінь учнів.

2. Планування (поурочне та річне) та організація навчально-виховного процесу.

3. Знання специфіки оцінювання класних і домашніх, усних і письмових робіт, уміння вести систематичний облік успішності учнів, аналізувати їх досягнення і недоліки для корекції своєї діяльності.

4. Постійне вдосконалення своєї професійної діяльності, готовність до подальшого професійного розвитку.

5. Здатність защікавити учнів і організувати навчальний процес таким чином, щоб діти засвоїли більшу частину матеріалу на уроці, а не самостійно.
6. Відповідальність за свої профресійні дії.

7. Уміння вчителя працювати з усім класом, малою групою і з окремими учнями з урахуванням їх індивідуальних особливостей.

8. Активна участь у шкільному житті.

9. Уміння цінувати допомогу колег та прагнення більше часу проводити в обговоренні з колегами нових методів і форм викладання.

Отже, підводячи підсумок, варто зазначити, що зміни у законодавстві стосовно професійно-педагогічної підготовки вчителів початкової школи в Україні та Великій Британії пов'язані з активними процесами професіоналізації педагогічної діяльності. Стандарт кваліфікованого вчителя є найбільш відповідним документом підготовки вчителів початкової школи на сучасному етапі. Він охоплюе більшість аспектів професійної підготовки, включаючи зміст і форми Національної програми підготовки вчителів з базових предметів. Виконання цієї програми розглядається як один із ключових елементів у планах уряду щодо досягнення і підвищення грамотності, а також щодо прогресу в досягненні цільових показників.

Розглянувши британський досвід системи вищої освіти, вважаємо доцільним удосконалити професійну підготовку майбутніх початкової школи та посилити роль учителя в суспільстві. Одним із важливих чинників цього є визначення вимог до майбутніх учителів, до їх професійної підготовки, яка повинна бути орієнтована на багатогранну майбутню професійну діяльність.

Професійна підготовка вчителів початкової школи повинна мати на меті не тільки засвоєння студентами сучасних знань із загальнопрофесійних і фахових дисциплін, виховання високоосвіченої, культурної, гармонійно розвиненої особистості, а й пропагувати ідеї інклюзивної освіти, здоров'язберігаючого та неперервного навчання, освіти в інтересах сталого розвитку, компетентнісного підходу, демократії, створення единої зони европейської освіти, толерантності.

Висновки і пропозиції. Відповідно до аналізу навчальних планів та програм підготовки майбутніх вчителів початкової школи стверджуємо, що навчальне навантаження українських студентів педагогічних навчальних закладів удвічі більше, ніж у британських. Також, компоненти змісту профресійної підготовки вчителів початкової школи України та Великобританії е одинакові: психолого-педагогічна підготовка, спеціально-предметна та педагогічна практика.

Нам вдалось з'ясувати, що у процесі підготовки вчителів у Великій Британії використовують різноманітні технології навчання (тьюторське, дистанщійне, модульне, кредитне, кредитно-модульне, персоніфіковане навчання, взаемне навчання), форми організації навчання (лекція, семінар, тьюторіал, дискусія, самостійна робота, лабораторна робота, практична робота, спільна рецензія на проекти і дисертації, телеконференція), методи контролю результатів навчання (письмові роботи (essays), письмові іспити та тестування, наукові дослідження, профессійний проект).

Можна зробити висновок щодо підготовки майбутніх учителів початкових класів у Великобританії, що позитивною характеристикою британської системи освіти вчителів є рівень знань випускників, сприяння педагогічними праців- 
никами недормальній освіті здобувачів, різноманітна структура позанавчальних курсів, і як результат - отримання престижного диплому. Британська система освіти міжнародно визнана, а її навчальні заклади є зразком впровадження інноваційних технологій.
Саме тому, вважаємо, що досвід Великобританії може бути використаний у системі підготовки майбутніх вчителів початкових класів України. Віримо, що це допоможе підвищити рівень вищої освіти майбутніх педагогів, а також, сприятиме міжкультурній комунікації країн.

\section{Список літератури:}

1. Гоцуляк К.І. Підготовка вчителя у системі післядипломної освіти до диференційованого навчання молодших школярів : авторедр. дис. ... кандидата пед. наук : 13.00.04. Хмельницький, 2016. 23 с.

2. Закон України «Про вищу освіту» від 01.07.2014 № 1556-VII. Голос Украӥни. 2014. № 148 (06.08.2014). C. 2-6.

3. Концепція «Нова школа. Простір освітніх можливостей». URL: http://mon.gov.ua/activity/education/ zagalnaserednya/ua-sch-2016/ (дата звернення: 15.06.2021).

4. Нос Л.С. Підготовка вчителів початкової школи в Канаді: теорія і практика : навч. посіб. / за ред. Н.Г. Ничкало, Бадікова Н.О. Львів, 2016. 300 с.

5. Носовець Н.М. Професійна підготовка майбутніх учителів у країнах західної Європи. Вісник Чернігівського національного педагогічного університету. Серія : Педагогічні науки. 2015. Вип. 130. С. 68-72.

6. Про Національну стратегію розвитку освіти в Україні на період до 2021 року : Указ Президента України від 25 червня 2013 р. № 344/2013 / Президент України. Офбіиійний вісник України. 2013. № 17. С. 31-39.

7. Рокосовик Н.В. Підготовка магістрів педагогіки в університетах Великої Британії засобами дистанційного навчання : автореф. дис. ... канд. пед. наук : 13.00.04 «Теорія і методика професійної освіти»; Рівненський державний гуманітарний університет. Рівне, 2016. 26 с.

8. Хижняк О. Використання позитивного досвіду Великобританії у підготовці майбутніх учителів в Україні. Порівняльно-педагогічні студіï. 2012. № 1(11).

9. Badri M., Elmourad T., Ferrandino V. The social cognitive model of work satisfaction among teachers: Testing and validations. International Journal of Education Research. 2013. Vol. 57. P. 12-24.

10. Brown H.D. Principles of English Learning and Teaching: Education Foundation. 2006. 138 p.

11. Brunner J.J. Toward a Theory of Institution Cambridge. Cambridge : Cambridge UP, 2010. 103 p.

12. Frymier J., Galloway C. Individualized Learning in School of Tomorrow. Theory into Practice. 2014 . Vol. XIII. 66 p.

13. Professional Standards for Qualified Teacher Status and Requirements for Initial Teacher Training. TDA, 2016.24 p.

\section{References:}

1. Hotsuliak K.I. (2016) Pidhotovka vchytelia u systemi pisliadyplomnoi osvity do dyferentsiiovanoho navchannia molodshykh shkoliariv [Pedagogical conditions of teacher training in the system of postgraduate education to differentiated learning junior pupils] (PhD Thesis), Khmelnytskyi.

2. Law of Ukraine "On Higher Education" [Zakon Ukrainy «Pro vyshchu osvitu»] 01.07.2014. Voice of Ukraine. 2014. P. 2-6.

3. The concept of "New school. Space of educational opportunities" [Kontseptsiia "Nova shkola. Prostir osvitnikh mozhlyvostei"]. URL: http://mon.gov.ua/activity/education/zagalna serednya/ua-sch-2016/

4. Nos L.S. (2016) Pidhotovka vchyteliv pochatkovoi shkoly v Kanadi: teoriia i praktyka [Primary School Teacher Training in Canada: Theory and Practice]. Lviv, $300 \mathrm{p}$.

5. Nosovets N.M. (2015) Profesiina pidhotovka maibutnikh uchyteliv u krainakh zakhidnoi Yevropy [Professional training of future teachers in Western Europe]. Visnyk Chernihivskoho natsionalnoho pedahohichnoho universytetu. Seriia: Pedahohichni nauky [Bulletin of Chernihiv National Pedagogical University. Series: Pedagogical sciences], vol. 130, pp. 68-72.

6. Pro Natsionalnu stratehiiu rozvytku osvity v Ukraini na period do 2021 roku: ukaz Prezydenta Ukrainy (2013) [On the National Strategy for the Development of Education in Ukraine until 2021: Decree of the President of Ukraine], pp. 31-39.

7. Rokosovyk N.V. (2016) Pidhotovka mahistriv pedahohiky v universytetakh Velykoi Brytanii zasobamy dystantsiinoho navchannia [Training of masters of pedagogy in British universities by means of distance learning]: (PhD Thesis); Rivne State University for the Humanities. Rivne, 26 p.

8. Khyzhniak O. (2012) Vykorystannia pozytyvnoho dosvidu Velykobrytanii u pidhotovtsi maibutnikh uchyteliv $\mathrm{v}$ Ukraini [Using the positive experience of the United Kingdom in the training of future teachers in Ukraine]. Porivnialno-pedahohichni studii [Comparative and pedagogical studies], vol. 1, no. 11.

9. Badri M., Elmourad T., Ferrandino V. (2013) The social cognitive model of work satisfaction among teachers: Testing and validations. International Journal of Education Research, vol. 57, pp. 12-24.

10. Brown H.D. (2006) Principles of English Learning and Teaching: Education Foundation, 138 p.

11. Brunner J.J. (2010) Toward a Theory of Institution Cambridge. Cambridge: Cambridge UP, 103 p.

12. Frymier J., Galloway C. (2014) Individualized Learning in School of Tomorrow. Theory into Practice, vol. XIII, 66 p.

13. Professional Standards for Qualified Teacher Status and Requirements for Initial Teacher Training (2016). TDA, 24 p. 